\title{
Binding of ${ }^{125}$ I-labelled FSH in the mouse testis in vitro
}

\author{
A. G. Davies, N. R. Lawrence and S. S. Lynch* \\ Department of Physiology, Medical School, Birmingham B15 2TJ and \\ *Department of Clinical Endocrinology, Women's Hospital, Birmingham BII 4HL, U.K.
}

\begin{abstract}
Summary. In-vivo testicular binding of highly purified pituitary $\mathrm{FSH}$, labelled by a method which did not significantly affect biological potency, was hormone-specific, tissue-specific and dose-dependent. Hypophysectomy of mice was followed by a progressive increase in the amount of ${ }^{125}$ I-labelled FSH per unit weight of test is but not in the total amount of hormone taken up by the testis. Maximum binding occurred at $4 \mathrm{~h}$ in a membrane-containing fraction prepared by high-speed ultracentrifugation of testicular homogenate. This is considerably later than has been reported for testicular tissue incubated in vitro at $37^{\circ} \mathrm{C}$.
\end{abstract}

\section{Introduction}

The binding of FSH to testicular tissue in vitro has been studied by Means \& Vaitukaitis (1972) who incubated testicular tissue from 20-day-old rats with tritiated $\mathrm{FSH}$ and found that at $37^{\circ} \mathrm{C}$ maximum binding occurred within 1 h of the start of incubation. Until receptor capacity was saturated there was a linear relationship between the concentration of hormone in the medium and the amount of hormone which was bound. The binding was hormone-specific because only unlabelled hormones with FSH activity displaced labelled FSH. Steinberger, Thanki \& Siegal (1974) found that testicular tissue from intact adult rats and from rats hypophysectomized between 3 and 37 days before killing had equal affinity for ${ }^{125} \mathrm{I}$-labelled FSH. Again maximum binding occurred within $1 \mathrm{~h}$ and binding was both tissue-specific and hormone-specific.

The investigations reported here were undertaken to find out how accurately the characteristics of FSH binding to the test is of the living animal are reflected by the results of in-vitro experiments. Mice rather than rats were used so that smaller amounts of labelled hormone were required.

\section{Materials and Methods}

\section{Iodination}

Sodium ${ }^{125}$ iodide ( $5 \mathrm{mCi}$ in $50 \mu \mathrm{l} \mathrm{NaOH}$, IMS 30: Radiochemical Centre, Amersham) was diluted with $0.5 \mathrm{M}$-sodium phosphate, $\mathrm{pH} 7 \cdot 5$, to give a stock solution of $40 \mu \mathrm{Ci} / \mu \mathrm{l}$. For injection this solution was diluted in $0.05 \mathrm{M}$-sodium phosphate buffer, $\mathrm{pH} 7.2$, containing $0.1 \%$ BSA (Armour Pharmaceutical Co. Ltd).

FSH. Human pituitary FSH containing 10850 i.u. FSH and 150 i.u. LH/mg (Butt \& Lynch, 1974) was iodinated by the following modification of the chlorine gas method (Butt, 1972). FSH (1 $\mu \mathrm{g})$ in $5 \mu \mathrm{l} 0.05 \mathrm{M}$-sodium phosphate, $\mathrm{pH} 7.5$ was mixed with $5 \mu \mathrm{l} \mathrm{Na}{ }^{125} \mathrm{I}$ stock solution $(200 \mu \mathrm{Ci})$ in a $0.75 \mathrm{ml}$ stoppered conical polystyrene tube (30/8: Walter Sarstedt, Leicester). A solution of $50 \mu \mathrm{g} \mathrm{NaCl}$ in $5 \mu \mathrm{l}$

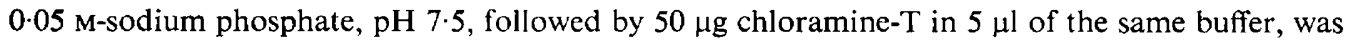
pipetted on to a $1-\mathrm{cm}$ square of Green's 401 filter paper which was wedged into the upper part of the neck of the tube. The tube was immediately stoppered and gently vortexed for a few seconds every minute for $5 \mathrm{~min}$. The filter paper was then removed and discarded and the reaction in the tube was stopped by the addition of $250 \mu \mathrm{g}$ sodium metabisulphite in $50 \mu \mathrm{l} 0.05 \mathrm{M}$-sodium phosphate, $\mathrm{pH} 7 \cdot 5$, and the separation of the iodide and the iodinated protein was completed in the usual manner. Specific 
activities of $80-114 \mu \mathrm{Ci} / \mu \mathrm{g}$ were obtained. Unlabelled FSH used for competitive binding studies contained 700 i.u. FSH and 150 i.u. LH/mg, as judged by radioimmunoassay with MRC 69/104 as standard. The hCG was obtained from Paines and Byrne and had an LH activity of $1550 \mathrm{i} . \mathrm{u} . / \mathrm{mg}$ and an FSH activity of $<15$ i.u./mg.

Albumin. Human serum albumin (Sigma) was iodinated to a specific activity of $175 \mu \mathrm{Ci} / \mathrm{mg}$ by the same method as for FSH.

\section{Animals}

CFW mice from the departmental colony were used. Hypophysectomy was carried out by the parapharyngeal approach at 60-70 days of age and the mice were used for experiments 9-11 days later. At autopsy the sella turcica of each mouse was examined with the naked eye and no pituitary fragments were present. The absence of pituitary cells in serial histological sections of the sellae from 5 hypophysectomized mice confirmed the adequacy of naked-eye appraisal. Plasma samples from 8 hypophysectomized mice were assayed for endogenous FSH and no FSH was detectable (limit of assay sensitivity: $40 \mathrm{ng} / \mathrm{ml}$; range in intact mice: $1320-2200 \mathrm{ng} / \mathrm{ml}$ ). Intact control animals were killed at the same age as hypophysectomized mice.

Hormones were injected into a tail vein. The actual dose of FSH given depended on the specific activity and availability of material at the time of a particular experiment. In the dose-response experiment (Exp. 4), the doses were from 0.02 to $1.8 \mathrm{i}$.u. in $0.2 \mathrm{ml}$ phosphate-buffered saline, $\mathrm{pH} 7.2$, containing $0 \cdot 1 \% \mathrm{BSA}$. In all other experiments, the single dose was $2 \cdot 0-4 \cdot 6 \mu \mathrm{Ci}(0 \cdot 15-0 \cdot 38 \mathrm{i} . \mathrm{u} \text {. })^{125} \mathrm{I}-\mathrm{labelled}$ FSH in $0 \cdot 2-0.3 \mathrm{ml}$ phosphate-buffered saline, pH $7 \cdot 2$, containing $0 \cdot 1 \% \mathrm{BSA}$.

\section{Preparation of membrane-containing fraction}

After removal of the tunica albuginea one testis was homogenized in $2 \mathrm{ml}$ sodium phosphate-

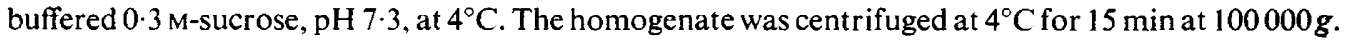
The pellet, containing nuclei, ribosomes, mitochondria and plasma membranes, was washed 4 times by resuspension in buffer and centrifugation under the same conditions. Finally the pellet was resuspended and aliquots of this suspension were taken for measurement of protein concentration by the method of Geiger \& Bessman (1972) and of radioactivity by gamma-ray spectrometry.

\section{Experiments}

Experiment 1. The biological activity of labelled and unlabelled FSH was assayed by the ovarian augmentation method in mice (Brown, 1955). The augmenting dose of hCG was 50 i.u. The assays were performed with 3 animals at each of 4 dose levels, with a dose interval of 2. The M.R.C. 2nd IRP HMG was used as standard.

Experiment 2. The time course of accumulation and loss of ${ }^{125} \mathrm{I}$-labelled FSH was studied in whole tissue samples of testis after removal of the tunica and in liver and muscle tissue from groups of 4 hypophysectomized mice treated with labelled hormone $4 \mathrm{~min}$ to $16 \mathrm{~h}$ before death.

Experiment 3. The uptake of labelled FSH was measured in groups of 4 mice hypophysectomized 7,14 or 28 days previously and in a group of 4 intact animals. The hormone was administered intravenously $2 \mathrm{~h}$ before death. Histological sections of test is were prepared from groups of 3 mice 7,14 or 28 days after hypophysectomy and from 3 intact animals. For each mouse counts were made of the cells in two transverse sections of tubules at stage 7 of the cycle of the seminiferous epithelium (Oakberg, 1956).

Experiment 4 . Groups of 4 hypophysectomized mice were injected intravenously with $0 \cdot 02,0.07$, $0.2,0.6$ or 1.8 i.u. ${ }^{125}$ I-labelled FSH and killed $2 \mathrm{~h}$ later. The specific radioactivity in a membranecontaining fraction of the testicular homogenate was measured.

Experiment 5. The specificity of binding to membrane-containing fractions prepared by ultracentrifugation of homogenates of test is and liver tissue was investigated in 3 groups of 4 hypophysectomized mice treated with labelled FSH (0.15 i.u.) $4 \mathrm{~h}$ before killing and with saline, unlabelled FSH ( 15 i.u.) or hCG (15 i.u.) $2 \mathrm{~h}$ before killing. Two groups of 4 intact mice received injections of labelled FSH and saline, or labelled and unlabelled FSH. 
Experiment 6. Membrane-bound radioactivity was compared in testicular and liver tissue from groups of 4 mice treated with ${ }^{125} \mathrm{I}$-labelled $\mathrm{FSH},{ }^{125} \mathrm{I}$-labelled albumin or sodium ${ }^{125}$ iodide, 15 min to $8 \mathrm{~h}$ before death.

Experiment 7. The proportion of ${ }^{125} \mathrm{I}$-labelled FSH to free ${ }^{125} \mathrm{I}$ was determined by chromatographing $0.2 \mathrm{ml}$ samples of plasma or homogenate supernatant on a $20 \times 1 \mathrm{~cm}$ column of Sephadex G-25 in 0.05 M-sodium phosphate buffer, $\mathrm{pH} \mathrm{7.5}$. Twenty $2-\mathrm{ml}$ fractions were collected and counted separately in a gamma scintillation counter.

\section{Statistical methods}

The bioassay results were calculated by the method of Borth (1960). Other results were assessed by linear regression, Student's $t$ test and analysis of variance (Snedecor \& Cochran, 1967).

\section{Results}

An equal dose of ${ }^{125}$ I-labelled FSH was given to all mice used in an experiment, but because differing amounts of activity were used in different experiments the results have been corrected to a dose of $2.5 \mu \mathrm{Ci}$, except in the dose-response experiment.

\section{Experiment 1: bioassay of FSH}

The biological activity of the highly purified FSH preparation was $10850 \mathrm{i} . \mathrm{u} . / \mathrm{mg}$ before labelling (95\% confidence limits: 5610-20 840) and that of the labelled FSH was 12410 i.u./mg (95\% confidence limits: $6500-24250$ ). These values were thus not significantly different from one another.

\section{Experiment 2: uptake and loss of FSH}

The specific radioactivities in testis, muscle and liver tissue at various times after injection of labelled FSH are shown in Table 1 . In the testis the highest level of total activity occurred 2 and $4 \mathrm{~h}$ after administration of the hormone. Blood and liver specific radioactivity declined from shortly after administration of labelled FSH to the steady level found in the 8- and 16-h specimens.

Table 1. Specific radioactivity, in c.p.m./mg wet weight of tissue (mean \pm s.e.m., $n=4$ ), in mouse tissues after treatment in vivo with ${ }^{125}$ I-labelled FSH (results corrected to a standard dose of $2 \cdot 5 \mu \mathrm{Ci})$

\begin{tabular}{lccc}
\hline $\begin{array}{c}\text { Time after } \\
\text { FSH treatment }\end{array}$ & Testis & Muscle & Liver \\
\hline & & & \\
\hline $4 \mathrm{~min}$ & $15 \pm 2$ & $26 \pm 6$ & $127 \pm 11$ \\
$8 \mathrm{~min}$ & $19 \pm 3$ & $26 \pm 6$ & $140 \pm 10$ \\
$15 \mathrm{~min}$ & $35 \pm 5$ & $34 \pm 6$ & $189 \pm 20$ \\
$30 \mathrm{~min}$ & $45 \pm 3$ & $23 \pm 2$ & $145 \pm 8$ \\
$1 \mathrm{~h}$ & $58 \pm 2$ & $28 \pm 3$ & $152 \pm 9$ \\
$2 \mathrm{~h}$ & $63 \pm 4$ & $40 \pm 4$ & $111 \pm 4$ \\
$4 \mathrm{~h}$ & $62 \pm 5$ & $38 \pm 3$ & $92+4$ \\
$8 \mathrm{~h}$ & $52 \pm 4$ & $37 \pm 2$ & $64 \pm 5$ \\
$16 \mathrm{~h}$ & $53 \pm 5$ & $33 \pm 2$ & $66 \pm 4$ \\
\hline
\end{tabular}

\section{Experiment 3: effect of hypophysectomy on FSH uptake}

By $2 \mathrm{~h}$ after administration of labelled FSH the specific radioactivity in the test is was greater in hypophysectomized than in intact mice and increased with the time after the operation (Table 2). 
Hypophysectomy was not followed by significant changes in specific radioactivity in liver or muscle $(P<0.05)$. The number of step 16 spermatids per 100 Sertoli cells had fallen to $60 \%$ of the control level by 7 days after hypophysectomy and to $5 \%$ by 28 days, at which time the number of step 7 spermatids was $33 \%$ of the control level.

Table 2. Effects of hypophysectomy on accumulation of ${ }^{125}$ I-labelled FSH in test is (mean \pm s.e.m., $n=4$ ) of mice treated with ${ }^{125} \mathrm{l}$-labelled FSH (a standardized dose of $2.5 \mu \mathrm{Ci}) 2 \mathrm{~h}$ before death

\begin{tabular}{cccc}
\hline $\begin{array}{c}\text { Time after } \\
\text { hypophysectomy } \\
\text { (days) }\end{array}$ & $\begin{array}{c}\text { Total activity } \\
\text { (c.p.m./testis) }\end{array}$ & $\begin{array}{c}\text { Weight } \\
\text { (mg/testis) }\end{array}$ & $\begin{array}{c}\text { Specific activity } \\
\text { (c.p.m./mg) }\end{array}$ \\
\hline 0 (intact control) & $2718 \pm 150$ & $96 \pm 4$ & $28 \pm 1$ \\
7 & $3017 \pm 167$ & $81 \pm 4$ & $38 \pm 2$ \\
14 & $2312 \pm 294$ & $61 \pm 11$ & $47 \pm 7$ \\
28 & $1193 \pm 208$ & $24 \pm 5$ & $51 \pm 5$ \\
\hline
\end{tabular}

\section{Experiment 4: dose response}

Increasing the dose of ${ }^{125}$ I-labelled FSH from 0.02 to $1.8 \mathrm{i}$.u. caused a linear increase of radioactivity (mean \pm s.e.m.) in the testicular membrane-containing fraction from $53 \pm 6$ to $1739 \pm 190$ c.p.m./mg protein $(r=0.959, P<0.001)$.

\section{Experiment 5: specificity of binding}

In the testes of hypophysectomized mice, a 100-fold larger dose of unlabelled FSH (15 i.u.) displaced $40 \%$ of the ${ }^{125}$ I-labelled FSH from the membrane-containing fraction $(P<0.025)$ (Table 3$)$ but displacement in the testes of intact animals was not significant $(P<0.05)$. FSH did not displace activity from the liver in either group of animals. In hypophysectomized mice 15 i.u. hCG did not significantly affect the amount of ${ }^{125} \mathrm{I}$-labelled $\mathrm{FSH}$ remaining in test is or liver fractions or in blood $(P>0.05)$.

Table 3. Percentage change in the specific radioactivity in membrane-containing fractions of testis and liver and in blood from mice (4/group) given unlabelled FSH 2 h after treatment with ${ }^{125}$ I-labelled FSH and killed 2 h later

\begin{tabular}{cccc}
\hline Treatment & Testis & Liver & Blood \\
\hline $\begin{array}{c}\text { Hypophysectomized mice } \\
\text { Labelled FSH } \\
\text { Labelled FSH }+ \\
\quad \text { unlabelled FSH }\end{array}$ & 100 & 100 & 100 \\
$\begin{array}{l}\text { Labelled FSH }+ \\
\text { unlabelled hCG }\end{array}$ & $60 \pm 9$ & $123 \pm 23$ & $107 \pm 4$ \\
$\begin{array}{c}\text { Intact mice } \\
\text { Labelled FSH } \\
\text { Labelled FSH }+ \\
\text { unlabelled FSH }\end{array}$ & $89 \pm 20$ & $118 \pm 14$ & $88 \pm 7$ \\
\hline
\end{tabular}

\section{Experiment 6: comparison of uptakes of FSH, albumin and sodium iodide}

Higher specific activities of label were found in test is and liver at all times after administration of labelled albumin (Table 4). In the membrane-containing pellet from the test is the highest levels of FSH and albumin were in the 4-h specimens, but albumin-treated animals were not killed at times after this. Very little iodide was taken up by the membrane fraction of testis ( $<10$ c.p.m./mg protein) or liver ( $<20$ c.p.m.) during this experiment, and the test is to blood rat io did not rise above $0 \cdot 01$. Data in Table 4 show that initially the half-life of FSH in plasma was $45 \mathrm{~min}$. 
Table 4. Specific radioactivity in the membrane-containing fraction of tissue and in blood of mice after treatment with $2.5 \mu \mathrm{Ci}^{125} \mathrm{I}$-labelled FSH or ${ }^{125} \mathrm{I}$-labelled albumin

\begin{tabular}{clccc}
\hline $\begin{array}{l}\text { Time after } \\
\text { treatment }\end{array}$ & Treatment & $\begin{array}{c}\text { Testis } \\
\text { (c.p.m./mg protein) }\end{array}$ & $\begin{array}{c}\text { Liver } \\
\text { (c.p.m./mg protein) }\end{array}$ & $\begin{array}{c}\text { Blood } \\
\text { (c.p.m./ } / \mu l)\end{array}$ \\
\hline \multirow{2}{*}{$15 \mathrm{~min}$} & FSH & $34 \pm 7$ & $642 \pm 39$ & $881 \pm 98$ \\
& Albumin & $21 \pm 3$ & $162 \pm 14$ & $908 \pm 59$ \\
$1 \mathrm{~h}$ & FSH & $187 \pm 17$ & $503 \pm 32$ & $436 \pm 21$ \\
& Albumin & $35 \pm 6$ & $111 \pm 17$ & $706 \pm 14$ \\
$2 \mathrm{~h}$ & FSH & $356 \pm 26$ & $429 \pm 39$ & $307 \pm 13$ \\
& Albumin & $41 \pm 5$ & $84 \pm 4$ & $502 \pm 27$ \\
& FSH & $464 \pm 41$ & $286 \pm 58$ & $238 \pm 5$ \\
& Albumin & $50 \pm 3$ & $65 \pm 9$ & $400 \pm 32$ \\
& FSH & $322 \pm 15$ & $171 \pm 8$ & $175 \pm 15$ \\
\hline
\end{tabular}

\section{Experiment 7: gel filtration}

Filtration of blood plasma on Sephadex G25 showed that at 30 and $90 \mathrm{~min}$ after administration of ${ }^{125} \mathrm{I}$-labelled FSH less than $13 \%$ of the radioactivity was free ${ }^{125} \mathrm{I}$ whereas at $13 \mathrm{~h} 33 \%$ of the ${ }^{125} \mathrm{I}$ was free. The proportion of free ${ }^{125} \mathrm{I}$ in the liver homogenate at $13 \mathrm{~h}$ was also $33 \%$.

\section{Discussion}

Follicle-stimulating hormone was labelled with iodide- 125 by a method which did not alter the biological activity significantly. In the mouse the highest levels of radioactivity were found 2 and $4 \mathrm{~h}$ after intravenous administration of this preparation, and the highest levels of membrane-bound activity occurred at $4 \mathrm{~h}$. In rat testicular tissue maximum levels of labelled FSH were reached in vitro at $37^{\circ} \mathrm{C}$ between 30 and $60 \mathrm{~min}$ (Means \& Vaitukaitis, 1972; Steinberger et al., 1974). The rapidity of uptake we observed in mice in vitro was presumably due to absence of the blood-testis barrier. In the rat, Setchell, Hinton, Jacks \& Davies (1976) found that little ${ }^{125}$ I-labelled FSH had entered seminiferous tubular fluid by $16 \mathrm{~h}$ after administration of the labelled hormone, and in the ram, Setchell \& Wallace (1972) showed that the peak concentration of radioactivity in rete test is fluid occurred more than $24 \mathrm{~h}$ after intravenous injection of the labelled FSH. FSH therefore appears to penetrate the blood-testis barrier relatively slowly under physiological conditions. The results of the present study lead to the same conclusion; the highest levels of FSH were found 2 and $4 \mathrm{~h}$ after administration of the hormone although the time for reduction of plasma level by $50 \%$ was $45 \mathrm{~min}$.

Steinberger et al. (1974) found that testicular tissue from intact and hypophysectomized rats had equal affinity for FSH in vitro. However, in the present experiments hypophysectomy was followed by an increase in specific radioactivity in the test is after administration of ${ }^{125} \mathrm{I}$-labelled FSH. This increase was thought to be due to lack of competition for binding sites by endogenous FSH and, as the more mature germinal cells decreased in number, to an increase in the proportion of cells to which FSH bound. By 28 days after hypophysectomy the total binding capacity of the testis was reduced, presumably because hypophysectomy was followed by diminished secretion of androgen, upon which the sensitivity of the testis to FSH is known to depend (Hansson et al., 1975). These findings and the present results suggest that androgen augments the action of FSH by inducing and maintaining testicular FSH receptors. Within the seminiferous tubule, FSH is localized in the basal compartment which contains Sertoli cells and spermatogonia (Castro, Alonso \& Mancini, 1972; Orth \& Christensen, 1977), and experiments on tissue from prenatally irradiated rats suggest that the Sertoli cells are the main target for FSH (Means, Fakunding, Huckins, Tindall \& Vitale, 1976).

Over the range of doses used, membrane-bound activity was proportional to dose, so it is probable that the largest dose did not saturate binding capacity. This dose was 10 times the amount which, given subcutaneously, stimulates maximum incorporation of amino acid into testicular protein (Lawrence 
\& Davies, 1977). Only a small proportion of the binding sites for chorionic gonadotrophin need be occupied for maximum stimulation of testosterone synthesis (Catt \& Dufau, 1973); the present results show that the test is also has an excessive receptor capacity for FSH. This may be one reason why the 100 -fold larger dose of unlabelled FSH did not displace more than $40 \%$ of the labelled hormone, but in addition a proportion of the binding was presumably of the non-displaceable type found in tissues which are not targets for the hormone.

The test is bound more FSH than albumin. This might have been due to a special mechanism for FSH transport in the testis or the larger molecular size of albumin may have reduced its rate of passage through the endothelium of the testicular capillaries and into the tubules. The greater accumulation of FSH than of albumin in the liver is presumably associated with the liver's role in the removal of FSH from the circulation. As there was no appreciable binding of sodium iodide in testis or liver, the results of the other experiments could not have been due to liberation of iodine-125 from labelled FSH or albumin. Furthermore, gel filtration showed that a relatively small proportion of radioactivity in the plasma was due to ${ }^{125} \mathrm{I}$ liberated from the labelled hormone.

We thank the Medical Research Council for financial support and for provision of standard preparations of gonadotrophin. We are grateful to Dr P. C. Sivelle for assaying FSH in mouse plasma, using reagents made available by courtesy of the N.I.H.

\section{References}

BoRTH, R. (1960) Simplified mathematics for multiple bioassays. Acta endocr., Copenh. 35, 454-468.

Brown, P.S. (1955) The assay of gonadotrophin from urine of non-pregnant human subjects. J. Endocr. 13, 59-64.

Butr, W.R. (1972) The iodination of follicle-stimulating and other hormones for radioimmunoassay. $J$. Endocr. 55, 453-454.

BuTt, W.R. \& LYNCH, S.S. (1974) Techniques for the purification of human pituitary follicle-stimulating hormone. Biochem. Soc. Trans. 2, 785-787.

Castro, A.E., Alonso, A. \& Mancini, R.E. (1972) Localization of follicle-stimulating and luteinizing hormones in the rat testis using immuno-histological tests. J. Endocr. 52, 129-136.

CATT, K.J. \& DUfaU, M. (1973) Spare gonadotrophin receptors in rat testis. Nature, New Biol. 244, 219-211.

Geiger, P.J. \& Bessman, S.P. (1972) Protein determination by Lowry's method in the presence of sulfhydryl reagents. Analyt. Biochem. 49, 467-473.

Hansson, V., Weddington, S.C., Naess, O., AttraMADAl, A., French, F.S., Kotite, N., NAYFeH, S.N., RutzéN, E.M. \& HaGenas, L. (1975) Testicular androgen binding protein (ABP) - a parameter of Sertoli cell secretory function. In Hormonal Regulation of Spermatogenesis, pp. 323-336. Eds F. S. French, V. Hansson, E. M. Ritzén \& H. Nayfeh. Plenum Press, New York.

LAWRENCE, N.R. \& DAvies, A.G. (1977) Stimulation of testicular protein synthesis in vivo by gonadotrophins and growth hormone in hypophysectomized adult mice. J. Reprod. Fert. 48, 41-45.
Means, A.R. \& Vaitukaitis, J. (1972) Peptide hormone receptors: specific binding of ${ }^{3} \mathrm{H}-\mathrm{FSH}$ to testis. Endocrinology 90, 39-46.

Means, A.R., Fakunding, J.L., Huckins, C., Tindall, D.J. \& VITALE, R. (1976) Follicle-stimulating hormone, the Sertoli cell, and spermatogenesis. Recent Prog. Horm. Res. 32, 477-527.

OAKBERG, E.F. (1956) A description of spermiogenesis in the mouse and its use in analysis of the cycle of the seminiferous epithelium and germ cell renewal. $\mathrm{Am} . J$. Anat. 99, 391-413.

ORTH, J. \& Christensen, A.K. (1977) Localization of ${ }^{125} \mathrm{I}$-labelled FSH in the testes of hypophysectomized rats by autoradiography at the light and electron microscope levels. Endocrinology 101, 262-278.

Setchell, B.P. \& Wallace, A.L.C. (1972) The penetration of iodine-labelled follicle-stimulating hormone and albumin into the seminiferous tubules of sheep and rats. J. Endocr. 54, 67-77.

Setchell, B.P., Hinton, B.T., JACKS, F. \& Davies, R.V. (1976) Restricted penetration of iodinated rat FSH into the seminiferous tubules of the rat testis. Molec. cell. Endocr. 6, 59-70.

SNEdECOR, G.W. \& Cochran, W.G. (1967) Statistical Methods. Iowa State University Press, Ames, Iowa.

Steinberger, A., Thanki, K.H. \& Siegal, B. (1974) FSH binding in rat testis during maturation and following hypophysectomy. Cellular localization of FSH receptors. In Hormone Binding and Target Cell Activation in the Testis, pp. 177-191. Eds M. C. Dufau \& A. R. Means. Plenum Press, New York. 